\title{
Studies the response of gladiolus plants to humic acid, potassium and water irrigation intervals.
}

\author{
Amani Ismail Adam \\ Antoniadis Research Branch, Ornamental Plants Research and Landscape Gardening Res. Dept., Hort. Res. inst., \\ ARC, Alexandria, Egypt. \\ *Corresponding author email: amaniadm@ hotmail.com
}

Received on: 22-4-2021

Accepted on: 14-5-2021

\begin{abstract}
A field experiment was conducted on Gladiolus grown at the nursery of the Antoniadis Botanical Gardens, Horticulture Research Institute (HRI), ARC, Alex., Egypt., during two successive seasons 2018 and 2019 to study the influence of irrigation intervals ( 3 and 6 days) under three different levels of potassium sulphate $(\mathrm{K})$ fertilizer $(0,50$, and $100 \%)$ applied at $(1 \%$ and $2 \%)$ alone with three percentages of the recommended $\left(2 \mathrm{~g} \mathrm{pot}^{-1}\right)$ soil amended $\mathrm{K}$ with two levels of humic acid (HA) (1 and $\left.2 \mathrm{mll}^{-1}\right)$ as soil dressing to measure the vegetative growth, flowering traits, corms and cormels parameters and chemical components of leaves. The obtained results showed applying low water irrigation intervals under $100 \% \mathrm{~K}$ with 2 $\mathrm{mll}^{-1} \mathrm{HA}$ soil dressing gave the highest value in each of vegetative, flowering parameters, corm and cormels traits, chlorophyll $\mathrm{a}$ and $\mathrm{b}$, and chemical components $(\mathrm{K}, \mathrm{N}$ and $\mathrm{P})$ content in leaves. Nevertheless, a non-significant variation was detected in the leaf width, spike diameter, corm diameter, and dry weight of cormels in gladiolas plants. Plants grown without $\mathrm{K}$ and $1 \mathrm{mll}^{-1} \mathrm{HA}$ (control) gave the minimum values under both irrigation intervals in all parameters.
\end{abstract}

KEYWORDS: Gladiolus grandiflorus, Irrigation, Fertilizer, Nutrients, Chlorophyll Production

\section{INTRODUCTION}

Gladiolus grandiflorus L. (Gladiolus) belongs to the subfamily of Ixoidea and family Iridaceae, and most important (Manning and Goldblatt, 2008). Gladiolus is one of the important ornamental bulbous flowers grownup commercially in numerous parts of the world for its attractive flowers with diversity of colours, enormous form of flowerets and good keeping quality as a cut flower it has received its place of importance due to its usefulness in vases, flower decorates, bouquets, and to get great marketplace returns. Farther more, it may be detailed that the longevity or shelf life of its flowers is an important aspect of cut flower quality (Patra and Mohanty, 2015).

Drought is the most significant regulating factor for crop production and it is causes many problem in several regions of the world (Passioura, 2007). Shrubs and trees have much profounder and wider root systems than turf grass hence they should be irrigated less regularly but for longer irrigation intervals of time. The influences of drought are mainly severe on all types of seedlings and plants (Farahat $e t$ al., 2012). Prolonging the irrigation intervals had negative influence on plant height, fresh and dry masses of leaves, roots and content of carbohydrates in leaves and the opposite trend was noted in the root of Acacia saligna (El-Khateeb et al., 2011).

Potassium (K) is not a part of plant structure and even though it is very important as one of the macro-nutrients, it has a main role in internal reactions of the plant; therefore, it is named a quality element. The key role of $\mathrm{K}$ is to stimulate several enzymes in plant, for example a catalyst action for production of materials like protein and starch. Potassium moreover, sustains a role in photosynthesis, water structure of plant, cell growth stomatal regulation, osmotic modification, downloading hydrocarbons made in the leaf into phloem, transporting them inside the plant, anion-cation balance, and as supplementary in $\mathrm{N}^{+}$ transfer. Xiumei and Yaping (2003) showed that the usage of $\mathrm{K}$ has a main role in cumulative the yield. Also, the use of $\mathrm{K}_{2} \mathrm{O}$ would increase leaf area index (Azizi, 1998).

Humic acid (HA) is take out from diverse sources such as humus, peat, soil, coal, and oxidized lignite. Humic acid can directly have helpful influence on plant growth (vegetative and flowering) and increases the growth of roots and shoots \& absorption of nutrients i.e. phosphorus, calcium, magnesium, potassium, and nitrogen. Humic acid is stable by 


\section{Scientific Journal of Agricultural Sciences 3 (1): 23-37, 2021}

nature and is not hazardous for the soil, environment, and plant (Haghighi et al., 2011). Humic acid increases plant development through chelating diverse elements to overcome the absence of nutrients, and has helpful influence on production, growth increase, and quality improvement of agricultural products owing to having growth regulator compounds (Cacco, et al., 2000; Abdel-Mawgoud et al., 2007). The molecular and biochemical mechanisms underlying these actions are only partly known. HA is known to contain auxin and an "auxin-like" activity of HA has been suggested (Trevisan et al., 2010). Ghorbani et al., (2010) illustrated that between legume family plants; HA spray has significant influence on vegetative growth and increasing photosynthetic activity of plant. Sabzevari and Khazaei (2009) found that the interactive influence of different levels of HA at three spraying times on leaf area of wheat was significant. Sharif et al., (2002) indicated that HA could sustain photosynthetic tissues and thus dry mass (shoots and roots) would increase.

Hence, the main target of the present investigation was to study the effect of Humic acid with water irrigation intervals, different levels of two fertilizers application and percentage of the recommended potassium sulphate as soil addition, on the growth, flowerig yield quality and chemical components of gladiolus plants cultivar "Rose Supreme".

Table 1. Chemical analysis of the used soil

\begin{tabular}{llllllllll}
\hline $\mathrm{pH}$ & $\begin{array}{l}\mathrm{EC}\left(\mathrm{dsm}^{-1}\right) \\
\text { Cat }\end{array}$ & \multicolumn{2}{l}{ Ions $\left(\mathrm{meq} \mathrm{L}{ }^{-1}\right)$} \\
\cline { 2 - 10 } & $\mathrm{Na}^{+}$ & $\mathrm{Ca}^{++}$ & $\mathrm{Mg}^{++}$ & $\mathrm{K}^{+}$ & $\mathrm{HCO}_{3}^{-}$ & $\mathrm{CO}_{3}^{--}$ & $\mathrm{SO}_{4}^{--}$ & $\mathrm{Cl}^{-}$ \\
\hline 7.7 & 2.29 & 11.9 & 7.7 & 3.2 & 0.6 & 3.9 & 0.08 & 8.6 & 10.8 \\
\hline
\end{tabular}

The corms were planted in the nursery and three application methods were used in this research, as irrigation intervals treatment of corms (irrigating) and adding on the plant fertilizers (as soil dressing). Water irrigation intervals and adding plant fertilizers treatments were began three weeks after planting the corms in both seasons. Two water irrigation intervals treatments $(\mathrm{T} 1=$ three days (control) and $\mathrm{T} 2=$ six days of field capacity) were derived according to the amount of water inside by soils; this was measured as the variance among dry and wet sandy soil weight. Then control fertilizer levels of potassium sulphate (K1=0\% (control), $\mathrm{K} 2=50 \%$, and $\mathrm{K} 3=100 \%$ $\left(\mathrm{K}_{2} \mathrm{SO} 48 \%\right)$ ) were applied monthly (starting from three weeks after planting corms) during the growing season as soil dressing $\left(2 \mathrm{~g} \mathrm{pot}^{-1}\right)$ as suggested by Abbasi et al., (2005). Humic acid solutions at different levels were prepared by dissolving ( $\mathrm{H} 1=1$ (control)

\section{MATERIALS AND METHODS}

The present investigation was carried out in the nursery Ornamental research branch of the Antoniadis Botanical Gardens, Horticulture Research Institute (HRI), Agriculture research Center, Alex., Egypt. One commercial Gladiolus grandiflorus cultivar "Rose Supreme" was used and treated throughout two successive seasons of 2017 and 2018.

\subsection{Plant materials and treatments:}

Gladiolus corms ( $G$. grandiflorus cv. "Rose Supreme") were provided by a commercial nursery for ornamental plants and flowers in Cairo city that imported the corms from Netherlands (NL). These were irrigated atsintervals (three and six days) with three different levels $(0,50$, and $100 \%)$ of potassium sulphate $\left(\mathrm{K}_{2} \mathrm{O} 48 \%\right)$ under two concentrations of Humic acid (1 (control) and $\left.2 \mathrm{mll}^{-1}\right)$. The first season was planted on September 27, 2018, while the second season was done on September 24, 2019. Gladiolus was planted in $25-\mathrm{cm}$ plastic pots, one plant pot ${ }^{-1}$ that was filled by the used sandy soil. The fresh weight and average circumference of the chosen corms were 8.73 $\mathrm{g}$ and $8.87 \mathrm{~cm}$ (uniform sizes and shape). All the usual culture practices of growing gladiolus corms were applied as normal method.

The used soil for planting the corms was a sandy soil (sand $=90.1 \%$, silt $=4.7 \%$ and clay $=5.2 \%$ ) and the chemical analysis of it is displayed in Table 1. and $\mathrm{H} 2=2 \mathrm{mll}^{-1}$ ) as soil dressing that was also used during the entire experimental period (Table 1). Humic acid was applied two times at two weeks intervals mixing with water irrigation (after three weeks from planting corms) at two levels of application ( 1 and $2 \mathrm{mll}^{-1}$ ) by mixing of $\mathrm{HA}(70 \%)$ in one liter of water (Ultra-Humics, $\mathrm{Zn}=1100 \mathrm{ppm}$, $\mathrm{Mn}=700 \mathrm{ppm}, \mathrm{Fe}=500 \mathrm{ppm}$ and $\mathrm{PEG}=15 \%$; Agrico, Egypt). The HA used for treatment was the commercial product obtained from a Private Company in Alexandria. The treatments included two water irrigation intervals (3 and 6 days), and two different fertilizer source ( $\mathrm{K}$ and $\mathrm{HA}$ ). All gladiolus plants received NP fertilization quantities as suggested by Pandey et al., (2000). 


\subsection{Experimental layout and data measured:}

The investigational layout was a split-splitplot derivative in a randomized complete block design (RCBD) with three replications. Two water irrigation intervals were taken as the main plots; three foliar sprayed with potassium sulphate $(\mathrm{K})$ treatments were randomly allocated to the sub-main plots and two humic acid (HA) levels were derived to serve as the sub-sub-main plots. A random sample comprising 3 plants from each sub-sub-plot was selected to measure the following vegetative growth traits: plant height $(\mathrm{cm})$, number of leaves, leaf fresh and dry weights (g/plant), and leaf length and width $(\mathrm{cm})$. Flowering traits: Flowering date (day), spike length $(\mathrm{cm})$, spike diameter $(\mathrm{cm})$, spike fresh and dry weights, number of florets spike $^{-1}$, and floret diameter $(\mathrm{cm})$ were also recorded. Corm and cormels traits: Corm diameter $(\mathrm{cm})$, fresh and dry weights of corms $(\mathrm{g})$, number of cormels plant, and fresh and dry weights of cormels (g) were also measured. To obtain the dry weight, the samples were kept at $60^{\circ} \mathrm{C}$ for $72 \mathrm{~h}$ in an oven; then, weight was immediately measured.

\subsubsection{Chlorophylls (a and b) content of leaves:}

Eighty days later, at the end of the first season an analysis of the following chemical component was carried out. To record chlorophyll (chl a and b) content $\left(\mathrm{mg} \mathrm{g}^{-1}\right)$, we extracted chl. a and $\mathrm{b}$ from fresh leaf samples using $\mathrm{NN}$-dimethylformamid (DMF) through the flower bud initiation stage of both seasons, according to the technique considered by Porra et al., (1989) as formula : chl. a =11.65 A6642.69 A647, chl. $b=20.81$ A647- 4.53 A664

\subsubsection{Chemical components of leaves:}

All chemical components ( $\mathrm{K}, \mathrm{N}$, and $\mathrm{P}$ ) were measured in the sample solution using the A.O.A.C. (1995) process. Carbohydrate content (\%) was recorded in dry leaf samples according to the technique of Bates et al., (1973).

\section{RESULTS AND DISCUSSION}

The vegetative growth, flower yield, corms and cormels of the gladiolus and the intervals in irrigation water and the two different fertilizer source (K and HA) can be seen in Tables $2-4$.

\subsection{Vegetative growth traits:}

Plant height was significantly affected by interaction between the water irrigation intervals, potassium and humic acid as soil dressing application treatments, in both seasons as shown in Table (2).

In both seasons, a in comparison between water irrigation intervals showed that plants achieved the tallest plants in 3 days irrigation, $100 \%$ potassium sulphate and $2 \mathrm{mll}^{-1}$ humic acid (138.12 and 142.54 $\mathrm{cm})$, while the shortest plants were obtained in 6 days irrigation interval and $\mathrm{K} 1$ (control) and HA levels $(95.50$ and $109.33 \mathrm{~cm})$, respectively. Plant height decreased when irrigation increased, and with low levels of $\mathrm{K} 1$ and HA (control). Comparing the water irrigation intervals were showed that the 3 days irrigation was more effective to production than 6 days.

Statistical analysis showed that number of leaves and leaf length were highest significantly affected by interaction among the water irrigation intervals, K, and HA application treatments during both seasons as displayed in Table (2). Applying low water irrigation intervals under $100 \% \mathrm{~K} 3$ with $2 \mathrm{mll}^{-1}$ HA soil dressing gave a high leaf number and leaf length (10.01 and 9.80) and (60.54 and $58.35 \mathrm{~cm})$, respectively. Meanwhile applying the high water irrigation intervals under $0 \%$ (control) $\mathrm{K} 1$ combined with $1 \mathrm{mll}^{-1} \mathrm{HA}$ as soil dressing gave low leaf number and leaf length (7.05 and 7.03) and (43.35 and 40.67 $\mathrm{cm})$, respectively. In addition leaf width was insignificantly affected by interaction among the water irrigation intervals, $\mathrm{K}$ and $\mathrm{HA}$ as soil dressing application treatments during both seasons.

The growth of gladiolus, which was estimated as its leaf fresh and dry weights, was greatly affected by water irrigation intervals and high fertilizer levels, in both seasons (Table 2). Therefore, significant differences were found in the leaf fresh weight after applications with low level of irrigation and high (K3 and HA) fertilizer levels. Under low water irrigation intervals, the $100 \% \mathrm{~K} 3$ had high leaf fresh and dry weights in the $2 \mathrm{mll}^{-1} \mathrm{HA}$ (74.67 and $71.72 \mathrm{~g}$ ) and (13.37 and $12.90 \mathrm{~g})$, respectively; however, at the high water irrigation intervals, low leaf fresh and dry weights were found at $0 \% \mathrm{~K} 1$ and $1 \mathrm{mll}^{-1} \mathrm{HA}(48.53$ and $49.43 \mathrm{~g})$ and $(8.26$ and $7.41 \mathrm{~g})$, respectively. The noticed significant increase in vegetative growth performance as affected by applying water irrigation intervals, potassium and humic acid were sensed with numerous investigators and confirmed our work i.e., Ayoub (2005) mentioned that the shortest irrigation interval produced higher values of vegetative growth traits of plants. Furthermore, Ali and Mowafy (2003) considered the influence of different levels of $\mathrm{K}$ treatments on peanut in sandy soil and the cause revealed that $\mathrm{K}$ fertilizer increased number of branches 
Scientific Journal of Agricultural Sciences 3 (1): 23-37, 2021

Table 2. Effects of the interaction between irrigation intervals, potassium fertilization, and humic acid on vegetative growth traits of Gladiolus grandiflorus cv. "Rose Supreme" plants during the 2018 and 2019 seasons.

\begin{tabular}{|c|c|c|c|c|c|c|c|c|c|c|c|c|c|c|}
\hline \multirow{2}{*}{$\begin{array}{l}\text { Irrigation } \\
\text { intervals }\end{array}$} & \multirow{2}{*}{$\begin{array}{c}\mathrm{K} \\
\text { fertilizer }\end{array}$} & \multirow{2}{*}{$\begin{array}{c}\text { Humic } \\
\text { acid }\end{array}$} & \multicolumn{2}{|c|}{$\begin{array}{l}\text { Plant height } \\
\text { (cm) }\end{array}$} & \multicolumn{2}{|c|}{$\begin{array}{c}\text { Number of leaves } \\
\text { / plant }\end{array}$} & \multicolumn{2}{|c|}{$\begin{array}{l}\text { Leaf fresh weight } \\
\text { (g) }\end{array}$} & \multicolumn{2}{|c|}{$\begin{array}{l}\text { Leaf dry weight } \\
\text { (g) }\end{array}$} & \multicolumn{2}{|c|}{$\begin{array}{l}\text { Leaf length } \\
\quad(\mathrm{cm})\end{array}$} & \multicolumn{2}{|c|}{$\begin{array}{l}\text { Leaf width } \\
\qquad(\mathrm{cm})\end{array}$} \\
\hline & & & $1^{\mathrm{st}}$ & $2^{\text {nd }}$ & $1^{1^{\mathrm{st}}}$ & $2^{\text {nd }}$ & $1^{\mathrm{st}}$ & $2^{\text {nd }}$ & $1^{1^{\mathrm{st}}}$ & $2^{\underline{\text { nd }}}$ & $1^{\mathrm{st}}$ & $2^{\underline{\mathrm{nd}}}$ & $1^{\mathrm{st}}$ & $2^{\mathrm{nd}}$ \\
\hline \multirow{6}{*}{3 days } & \multirow{2}{*}{$\begin{array}{c}0 \% \\
\text { (Control) }\end{array}$} & $1 \mathrm{ml} / \mathrm{l}$ & $107.20 \mathrm{~h}$ & $112.61 \mathrm{i}$ & $7.16 \mathrm{c}$ & $7.07 \mathrm{~b}$ & $52.91 \mathrm{~h}$ & $50.98 \mathrm{~g}$ & $8.67 \mathrm{ef}$ & $7.63 \mathrm{ef}$ & $45.23 \mathrm{~g}$ & $43.08 \mathrm{~h}$ & $2.53 \mathrm{a}$ & $2.45 \mathrm{a}$ \\
\hline & & $2 \mathrm{ml} / \mathrm{l}$ & $110.68 \mathrm{~g}$ & $118.36 \mathrm{~h}$ & $7.24 \mathrm{c}$ & $7.13 b$ & $56.89 \mathrm{f}$ & $55.51 \mathrm{e}$ & 9.35def & $8.87 \mathrm{cdef}$ & $47.57 f$ & $46.08 \mathrm{~g}$ & $2.61 \mathrm{a}$ & $2.53 \mathrm{a}$ \\
\hline & \multirow{2}{*}{$50 \%$} & $1 \mathrm{ml} / \mathrm{l}$ & $115.39 \mathrm{ef}$ & $121.22 \mathrm{~g}$ & 8.39abc & $8.26 \mathrm{ab}$ & $58.43 \mathrm{f}$ & $56.46 \mathrm{e}$ & $9.61 \mathrm{c}-\mathrm{f}$ & 9.38 cde & $50.59 \mathrm{e}$ & $48.15 \mathrm{ef}$ & $2.65 \mathrm{a}$ & $2.62 \mathrm{a}$ \\
\hline & & $2 \mathrm{ml} / \mathrm{l}$ & $120.59 d$ & $127.39 \mathrm{e}$ & $8.65 \mathrm{abc}$ & $8.57 \mathrm{ab}$ & $61.71 \mathrm{e}$ & $58.75 d$ & $10.69 \mathrm{~cd}$ & $9.97 \mathrm{bcd}$ & $53.54 d$ & $51.30 \mathrm{~d}$ & $2.67 \mathrm{a}$ & $2.65 \mathrm{a}$ \\
\hline & \multirow{2}{*}{$100 \%$} & $1 \mathrm{ml} / \mathrm{l}$ & $129.80 \mathrm{~b}$ & $135.40 \mathrm{c}$ & $9.25 \mathrm{ab}$ & $9.12 \mathrm{a}$ & $72.23 b$ & $68.75 b$ & $12.92 \mathrm{ab}$ & $11.67 \mathrm{ab}$ & $58.67 \mathrm{~b}$ & $56.55 \mathrm{~b}$ & $2.74 \mathrm{a}$ & $271 \mathrm{a}$ \\
\hline & & $2 \mathrm{ml} / \mathrm{l}$ & $138.12 \mathrm{a}$ & $142.54 \mathrm{a}$ & $10.01 \mathrm{a}$ & $9.80 \mathrm{a}$ & $74.67 \mathrm{a}$ & $71.72 \mathrm{a}$ & $13.37 \mathrm{a}$ & $12.90 \mathrm{a}$ & $60.54 a$ & $58.35 \mathrm{a}$ & $2.89 a$ & $2.86 \mathrm{a}$ \\
\hline \multirow{6}{*}{6 days } & \multirow{2}{*}{$\begin{array}{c}0 \\
\text { (Control) }\end{array}$} & $1 \mathrm{ml} / 1$ & $95.50 \mathrm{j}$ & $109.33 \mathrm{j}$ & $7.05 c$ & $7.03 b$ & $48.53 \mathrm{i}$ & $49.43 \mathrm{~g}$ & $8.26 f$ & $7.41 \mathrm{f}$ & $43.35 \mathrm{~h}$ & $40.67 \mathrm{i}$ & $2.40 \mathrm{a}$ & $2.39 \mathrm{a}$ \\
\hline & & $2 \mathrm{ml} / 1$ & $100.00 \mathrm{i}$ & $113.76 \mathrm{i}$ & $7.19 \mathrm{c}$ & $7.09 \mathrm{~b}$ & $52.27 \mathrm{~h}$ & $53.13 \mathrm{f}$ & 9.11def & $8.49 \mathrm{def}$ & $45.59 \mathrm{~g}$ & $43.42 \mathrm{~h}$ & $2.54 \mathrm{a}$ & $2.49 \mathrm{a}$ \\
\hline & \multirow{2}{*}{$50 \%$} & $1 \mathrm{ml} / 1$ & 108.36h & $118.59 \mathrm{~h}$ & $7.59 b c$ & $8.15 \mathrm{ab}$ & $54.69 \mathrm{~g}$ & $54.87 \mathrm{e}$ & 9.31def & $8.78 \mathrm{cdef}$ & $47.29 \mathrm{f}$ & $46.55 \mathrm{fg}$ & $2.60 \mathrm{a}$ & $2.58 \mathrm{a}$ \\
\hline & & $2 \mathrm{ml} / \mathrm{l}$ & $114.06 \mathrm{f}$ & $123.52 \mathrm{f}$ & $8.78 \mathrm{abc}$ & $8.48 \mathrm{ab}$ & $58.02 \mathrm{f}$ & $56.60 \mathrm{e}$ & $10.18 \mathrm{cde}$ & $9.61 \mathrm{~cd}$ & $51.55 \mathrm{e}$ & $48.67 \mathrm{e}$ & $2.63 \mathrm{a}$ & $2.60 \mathrm{a}$ \\
\hline & \multirow{2}{*}{$100 \%$} & $1 \mathrm{ml} / 1$ & $116.77 \mathrm{e}$ & $132.10 d$ & $9.25 \mathrm{ab}$ & $9.06 \mathrm{a}$ & $67.26 \mathrm{~d}$ & $65.62 \mathrm{c}$ & $11.42 \mathrm{bc}$ & $10.49 b c$ & $54.61 d$ & $54.27 \mathrm{c}$ & $2.61 \mathrm{a}$ & $267 a$ \\
\hline & & $2 \mathrm{ml} / \mathrm{l}$ & $126.67 \mathrm{c}$ & $139.14 b$ & $9.90 \mathrm{a}$ & $9.64 a$ & $69.74 \mathrm{c}$ & $68.93 \mathrm{~b}$ & $12.46 a b$ & $11.71 \mathrm{ab}$ & $56.90 \mathrm{c}$ & $56.42 \mathrm{~b}$ & $2.67 \mathrm{a}$ & $2.82 \mathrm{a}$ \\
\hline
\end{tabular}


and leaf area plant $^{-1}$. Also, Thalooth et al., (2006) investigated the influence of foliar application of potassium, magnesium and zinc on vegetative growth of plants. They stated that $\mathrm{K}$ was superior in the growth traits of number of leaves, leaf area plant ${ }^{-1}$ and dry mass of leaves mungbean. Mazher et al., (2007) studied the effect of foliar K (25 and $50 \mathrm{ppm}$ ) on vegetative growth of Bauhinia plant and suggest that all growth parameters (plant height, leaf number, leaf area and shoot dry weight of shoot) were increased by increasing the levels of $\mathrm{K}$ as compared to the control. Humic acid is the cause of daughter-cell manufacture by meristematic cell divisions and subsequent huge development of the young cells. Under water lack, cell elongation of developed plants can be inhibited by interruption of water flow from the xylem to the surrounding elongating cells (Nonami, 1980).

The stimulating influences of irrigation intervals and fertilizing Gladiolus grandiflorus, L. plants with $\mathrm{K}$ and HA on the investigated vegetative growth performance could be attributed to the significantly improved biometric traits such as $\mathrm{N}$ metabolism and photosynthetic activity as well as the increase in number of leaves /plant (Baldotto and Baldotto, 2013). Thalooth et al. (2006) found that the enhancement influence of fertilizer on vegetative growth characteristics was very clear, hence treated plants resulted in taller and had a greater number of leaf number and mass of shoot. Such enhancement influence might be attributed to the effect of $\mathrm{K}$ on biological activity and metabolism also its stimulating result on enzyme activity and photosynthetic pigments which in turn encourage growth of plants (Michail et al., 2004).

The improved in plant height could be caused by either increasing the cell number of layers in cell expanding area and the cambial area or as a cause of water obtainability that increased cell enlargement over cell division (Abe and Nakai, 1999). Though, ElShakhs et al., (2002) reported that cumulative quality of water improved height of plant and leaf number on Dahlia plant. El-Hanafy et al., (2006) studied the influence of irrigation intervals (at 1, 3, 5, 7 and 9 days intervals) on the growth of Ornithogalum plant. The results showed that the shortest irrigation interval (at daily period) demonstrated its superiority in improving plant height, number of leaves plant ${ }^{-1}$. Bazaraa et al., (2012). Documented the influence of diverse irrigation intervals (1, 2 and 3 weeks) on vegetative growth traits on Gladiolus plant. They determined that plant height was decreased by prolonging irrigation interval.

\subsection{Flowering traits:}

It is apparent from data showen in Table (3) that all the interaction among the water irrigation intervals, K, and HA fertilizer levels of treatments significantly affected the studied flowering traits compared to the control, except for spike diameter of gladiolas exposed to both the water irrigation intervals, $\mathrm{K}$, and HA fertilizer levels (Table 3), which showed significant differences.

Data in Table (3) indicated that the 3 days water irrigation intervals under fertilizing the plants through $100 \% \mathrm{~K}$ with $2 \mathrm{mll}^{-1} \mathrm{HA}$ as soil dressing advanced the flowering date as a result of 9.13 and 8.32 days, for the first and second seasons, respectively. However, applying the 6 days water irrigation intervals under fertilizing the plants with $0 \%$ $\mathrm{K}$ combined with $1 \mathrm{mll}^{-1} \mathrm{HA}$ (control) as soil dressing caused a delay in flowering date in 9.29 and 8.40 days, for the first and second seasons, respectively.

As shown in Table (3), it is noticed that the highest values of spike length were measured as a result of applying the 3 days water irrigation intervals under fertilizing the plants with $100 \% \mathrm{~K}$ combined with $2 \mathrm{mll}^{-1} \mathrm{HA}$ as soil dressing for both seasons. This application produced an increase in spike length values of 33.04 and $34.30 \mathrm{~cm}$ in the first and second seasons, respectively compared to the control treatment (3 days water irrigation intervals under fertilizing the plants with $0 \% \mathrm{~K}$ with $1 \mathrm{mll}^{-1} \mathrm{HA}$ as soil dressing).

It is clear from the results illustrated in Table (3) that the significant effect on the number of florets/spike was achieved by applying the 3 days' water irrigation intervals under fertilizing the plants through $100 \% \mathrm{~K}$ with $2 \mathrm{ml}^{-1} \mathrm{HA}$ as soil dressing for both seasons. This application caused an increase in number of florets/spike (13.78 and 13.29) in the first and second seasons, respectively.

Data in Table (3) showed that the highest spike of fresh and dry weights were detected after applying the 3 days' water irrigation intervals under fertilizing the plants through $100 \% \mathrm{~K}$ with $2 \mathrm{mll}^{-1} \mathrm{HA}$ as soil dressing for both seasons. This application produced an increase in spike fresh and dry weights of (72.45 and $71.72 \mathrm{~g})$ and (13.04 and $12.27 \mathrm{~g})$ in the first and second seasons, respectively as compared to the control treatment.

In both seasons, the data presented in Table (3) showed that applying the 3 days water irrigation 
Scientific Journal of Agricultural Sciences 3 (1): 23-37, 2021

Table 3. Effects of the interaction between irrigation intervals, potassium fertilization, and humic acid on of flowering traits of Gladiolus grandiflorus cv. "Rose Supreme" plants during the 2018 and 2019 seasons.

\begin{tabular}{|c|c|c|c|c|c|c|c|c|c|c|c|c|c|c|c|c|}
\hline \multirow{2}{*}{$\begin{array}{l}\text { Irrigation } \\
\text { intervals }\end{array}$} & \multirow{2}{*}{$\begin{array}{c}\mathrm{K} \\
\text { fertilizer }\end{array}$} & \multirow{2}{*}{$\begin{array}{l}\text { Humic } \\
\text { acid }\end{array}$} & \multicolumn{2}{|c|}{$\begin{array}{c}\text { Flowering date } \\
\text { (days) }\end{array}$} & \multicolumn{2}{|c|}{$\begin{array}{l}\text { Spike length } \\
(\mathrm{cm})\end{array}$} & \multicolumn{2}{|c|}{$\begin{array}{c}\text { Spike } \\
\text { diameter }(\mathrm{cm})\end{array}$} & \multicolumn{2}{|c|}{$\begin{array}{l}\text { Spike fresh } \\
\text { weight }(\mathrm{g})\end{array}$} & \multicolumn{2}{|c|}{$\begin{array}{l}\text { Spike dry } \\
\text { weight (g) }\end{array}$} & \multicolumn{2}{|c|}{$\begin{array}{c}\text { No. of } \\
\text { florets/spike }\end{array}$} & \multicolumn{2}{|c|}{$\begin{array}{c}\text { Floret } \\
\text { diameter }(\mathrm{cm})\end{array}$} \\
\hline & & & $1^{\mathrm{st}}$ & $2^{\text {nd }}$ & $1^{\text {st }}$ & $2^{\text {nd }}$ & $1^{\mathrm{st}}$ & $2^{\text {nd }}$ & $1^{\text {st }}$ & $2^{\text {nd }}$ & $1^{\mathrm{st}}$ & $2^{\text {nd }}$ & $1^{\mathrm{st}}$ & $2^{\text {nd }}$ & $1^{\text {st }}$ & $2^{\text {nd }}$ \\
\hline \multirow{6}{*}{3 days } & \multirow{2}{*}{$\begin{array}{c}0 \% \\
\text { (Control) }\end{array}$} & $1 \mathrm{ml} / 1$ & $94.83 \mathrm{ab}$ & $94.10 \mathrm{ab}$ & $41.42 \mathrm{~h}$ & $40.28 \mathrm{~g}$ & $1.39 \mathrm{a}$ & $1.37 \mathrm{a}$ & $45.42 \mathrm{~h}$ & 43.40h & $6.87 \mathrm{ef}$ & $6.50 \mathrm{gh}$ & $9.97 \mathrm{c}$ & $9.56 \mathrm{de}$ & $8.66 f g$ & $8.72 \mathrm{e}$ \\
\hline & & $2 \mathrm{ml} / 1$ & $93.13 \mathrm{bcd}$ & $92.96 b c$ & $61.13 \mathrm{ef}$ & $58.98 \mathrm{e}$ & $1.44 \mathrm{a}$ & $1.58 \mathrm{a}$ & $51.96 f$ & $49.97 f$ & 8.37cde & $7.99 \mathrm{e}-\mathrm{h}$ & $11.09 b c$ & $10.88 \mathrm{bcd}$ & $9.25 \mathrm{fg}$ & 9.31de \\
\hline & \multirow{2}{*}{$50 \%$} & $1 \mathrm{ml} / \mathrm{l}$ & $92.46 \mathrm{~cd}$ & $91.63 \mathrm{~cd}$ & $62.46 \mathrm{de}$ & $59.91 \mathrm{e}$ & $1.70 \mathrm{a}$ & $1.66 \mathrm{a}$ & $59.43 d$ & $57.41 \mathrm{e}$ & $8.92 \mathrm{~cd}$ & 8.46def & $12.44 \mathrm{ab}$ & $12.09 \mathrm{abc}$ & $10.48 c-$ & $10.62 \mathrm{~cd}$ \\
\hline & & $2 \mathrm{ml} / 1$ & $91.40 \mathrm{~d}$ & 89.30ef & $68.68 b$ & $66.35 d$ & $1.88 \mathrm{a}$ & $1.84 \mathrm{a}$ & $66.70 \mathrm{~b}$ & $65.12 c$ & $10.96 \mathrm{~b}$ & $10.06 \mathrm{bcc}$ & $13.46 \mathrm{a}$ & $13.17 \mathrm{a}$ & $11.52 \mathrm{a}-\mathrm{c}$ & $11.65 \mathrm{bc}$ \\
\hline & \multirow{2}{*}{$100 \%$} & $1 \mathrm{ml} / \mathrm{l}$ & $87.40 \mathrm{ef}$ & $87.23 \mathrm{gh}$ & $69.54 b$ & $69.09 \mathrm{c}$ & $1.78 \mathrm{a}$ & $1.74 \mathrm{a}$ & $67.10 b$ & $64.65 c$ & $11.28 \mathrm{~b}$ & $10.47 b c$ & $13.64 \mathrm{a}$ & $13.21 \mathrm{a}$ & $12.52 \mathrm{ab}$ & $12.64 \mathrm{ab}$ \\
\hline & & $2 \mathrm{ml} / \mathrm{l}$ & $85.70 f$ & $86.10 \mathrm{~h}$ & $74.46 \mathrm{a}$ & $74.58 \mathrm{a}$ & $2.03 \mathrm{a}$ & $1.96 \mathrm{a}$ & $72.45 \mathrm{a}$ & $71.72 \mathrm{a}$ & $13.04 \mathrm{a}$ & $12.27 \mathrm{a}$ & $13.78 \mathrm{a}$ & $13.29 \mathrm{a}$ & $13.33 \mathrm{a}$ & $13.53 \mathrm{a}$ \\
\hline \multirow{6}{*}{6 days } & \multirow{2}{*}{$\begin{array}{c}0 \\
\text { (Control) }\end{array}$} & $1 \mathrm{ml} / 1$ & $96.33 \mathrm{a}$ & $95.20 \mathrm{a}$ & $37.73 \mathrm{i}$ & 37.77h & $1.30 \mathrm{a}$ & $1.32 \mathrm{a}$ & $41.42 \mathrm{i}$ & $40.63 \mathrm{i}$ & $6.03 \mathrm{f}$ & $6.28 \mathrm{~h}$ & $7.40 \mathrm{~d}$ & $8.28 \mathrm{e}$ & $8.38 \mathrm{~g}$ & $8.65 \mathrm{e}$ \\
\hline & & $2 \mathrm{ml} / 1$ & $94.40 \mathrm{~b}$ & $93.73 \mathrm{ab}$ & $56.22 \mathrm{~g}$ & $57.15 f$ & $1.52 \mathrm{a}$ & $1.54 \mathrm{a}$ & $48.40 \mathrm{~g}$ & $47.24 \mathrm{~g}$ & 7.26def & $7.46 \mathrm{fgh}$ & $9.60 \mathrm{c}$ & $10.68 \mathrm{~cd}$ & $8.72 \mathrm{fg}$ & $9.18 \mathrm{de}$ \\
\hline & \multirow{2}{*}{$50 \%$} & $1 \mathrm{ml} / 1$ & $93.40 b c$ & $92.73 b c$ & $60.50 f$ & $58.55 \mathrm{ef}$ & $1.54 \mathrm{a}$ & $1.63 \mathrm{a}$ & $56.14 \mathrm{e}$ & $56.04 \mathrm{e}$ & $8.35 \mathrm{cde}$ & $8.18 \mathrm{efg}$ & $12.10 \mathrm{ab}$ & $11.76 \mathrm{abc}$ & $9.58 \mathrm{efg}$ & $10.37 \mathrm{~cd}$ \\
\hline & & $2 \mathrm{ml} / \mathrm{l}$ & $92.16 \mathrm{~cd}$ & $90.63 \mathrm{de}$ & $64.08 \mathrm{~cd}$ & $64.74 d$ & $1.63 \mathrm{a}$ & $1.80 \mathrm{a}$ & $59.32 d$ & $62.71 d$ & $9.67 b c$ & $9.40 \mathrm{cde}$ & $13.18 \mathrm{a}$ & $12.47 \mathrm{abc}$ & $10.37 \mathrm{de}$ & $11.51 \mathrm{bc}$ \\
\hline & \multirow{2}{*}{$100 \%$} & $1 \mathrm{ml} / 1$ & $88.90 \mathrm{e}$ & $88.43 \mathrm{fg}$ & $64.58 c$ & $68.04 \mathrm{c}$ & $1.64 a$ & $1.70 \mathrm{a}$ & $63.30 c$ & $61.18 d$ & $10.17 b c$ & $10.40 \mathrm{bc}$ & $13.50 \mathrm{a}$ & $12.63 \mathrm{ab}$ & $11.24 b$ & $11.76 \mathrm{ab}$ \\
\hline & & $2 \mathrm{ml} / \mathrm{l}$ & $87.04 f$ & $86.80 \mathrm{gh}$ & $68.56 b$ & $72.28 b$ & $1.89 \mathrm{a}$ & $1.91 \mathrm{a}$ & $68.32 b$ & $66.94 b$ & $11.23 b$ & $11.69 \mathrm{ab}$ & $13.71 \mathrm{a}$ & $12.86 \mathrm{a}$ & $12.28 \mathrm{ab}$ & $13.19 \mathrm{ab}$ \\
\hline
\end{tabular}


intervals under fertilizing the plants with $100 \% \mathrm{~K}$ combined with $2 \mathrm{mll}^{-1} \mathrm{HA}$ as soil dressing produced the largest values of floret diameter (13.33 and 13.53 $\mathrm{cm}$ ) in both seasons, respectively. The combination between the shortest irrigation interval (3 days) and highest level of fertilizer K (100\%) and HA (2 mll-1) produced the maximum values of flowering parameters in Gladiolus plants.

Apparently, flowering traits (flowering date, spike length, spike diameter, number of florets/spike, spike fresh and dry weights, and floret diameter) were significantly affected by the 3 days water irrigation intervals under fertilizing the plants by $100 \% \mathrm{~K}$ combined with $2 \mathrm{ml} \mathrm{1-1} \mathrm{HA}$ as soil dressing (Table 3). Meanwhile, the flowering date was decreased in response to the decrease in water irrigation intervals (as recommended) with the highest fertilizer levels of $\mathrm{K}$ and HA.

In this context, the delay in flowering date related to the level of irrigation is in conformity with that documented by Nabih et al. (1992a) on Freesia plant. They suggested that prolonging irrigation interval to 4 weeks slightly delayed flowering. also, Nabih et al. (1992b) also mentioned that irrigation intervals of 7 and 12 days treatments improved flower quality and increased flowers yield on Polianthes tuberosa.

The results are in agreement with those found by Butt (2005) who stated that K significantly affected days number to spike emergence and first floret opening in gladiolus plant. Moreover, Mukesh et al. (2001) mentioned that foliar treatment of K resulted in higher corms number, floret diameter, and corm mass plant $^{-1}$ in Gladiolus plants. Younis et al. (2006) reported that nitrogen along with $\mathrm{K}$ and $\mathrm{P}$ has synergetic influence on flowering parameters in dahlias plant. Mohsin et al., (2015) on Gladiolus cv. "Essential" illustrated that the larger floret diameter was noted under application of $\mathrm{K}$ with $\mathrm{P}$. However, the high florets number spike ${ }^{-1}$ were obvious once $\mathrm{K}$ was applied alone.

The development in the investigated flowering traits as a cause of $\mathrm{K}$ application can be attributed to positive effect of $\mathrm{K}$ in floret improvement (Zubair, 2011). Arvinder et al., (2015) found that the stimulatory influences of foliar treatment of $\mathrm{K}$ might have caused in better accumulation of assimilates thus resulting in higher, sturdier and stronger stems of cut flowers carnation plant.

Babar et al. (2017) mentioned that the $\mathrm{N}$ and HA play significant role in vegetative and flowering growth of Gladiolus plant. Leaf area index and dry matter were augmented at density of 100 ppm HA and
$300 \mathrm{~kg} / \mathrm{ha} \mathrm{K}$ in cowpea plants (Motaghi and Nejad, 2014). Furthermore, El-Bably (2017) showed that plants received $9 \mathrm{mll}^{-1} \mathrm{HA}$ as soil drench method production a significant increase in flowering traits (number of florets spike $^{-1}$ and spike length) on tuberose plants.

\subsection{Corm and cormels traits:}

Data presented in Table (4) shows that the investigated traits of corm and cormels seemed to be significantly affected by irrigation intervals and two fertilizers treatments compared to the control. Except for, the corm diameter and dry weight of cormels of gladiolas which were not significantly affected by the different levels of $\mathrm{K}$ with $\mathrm{HA}$ under irrigation intervals, in both seasons.

It is clear from data in Table (4) that the high values of fresh and dry weights of corms were produced by applying the 3 days water irrigation intervals under fertilizing the plants by $100 \% \mathrm{~K}$ with 2 $\mathrm{mll}^{-1} \mathrm{HA}$ as soil dressing (44.25 and $42.71 \mathrm{~g}$ ) and $(8.20$ and $7.54 \mathrm{~g})$ for both seasons, respectively. Meanwhile, the fresh and dry weights of corms were decreased when the irrigation water was increased with $1 \mathrm{mll}^{-1} \mathrm{HA}$ and $0 \% \mathrm{~K}$ (25.12 and $\left.23.66 \mathrm{~g}\right)$ and (3.81 and $3.57 \mathrm{~g}$ ) for both seasons, respectively.

Data in Table (4) shows that the high effect on number of cormels/plant resulted from applying the 3 days water irrigation intervals under fertilizing the plants by $100 \% \mathrm{~K}$ with $2 \mathrm{mll}^{-1} \mathrm{HA}$ as soil dressing (15.83 and 15.01) for both seasons, respectively.

The highest values of fresh weight of cormels were recorded as a result of fertilizing the plants with $100 \% \mathrm{~K}$ with $2 \mathrm{mll}^{-1} \mathrm{HA}$ as soil dressing under 3 days water irrigation intervals (8.49 and $8.34 \mathrm{~g}$ ) for both seasons, respectively. Meanwhile the minimum values of fresh weight of cormels were obtained with applying 6 days water irrigation intervals without $\mathrm{K}$ fertilizing (4.35 and $4.21 \mathrm{~g})$ in both seasons, respectively.

The obtained data revealed that vegetative growth, flowering, corms and cormels traits were markedly increased after three days irrigation intervals with high level of $\mathrm{K}$ and HA. Three days irrigation intervals Gladiolus plants seemed to be more useful to irrigation than the six days irrigation intervals. The 3 days irrigation intervals with $100 \%$ potassium sulphate and $2 \mathrm{ml} \mathrm{l}^{-1}$ humic acid led to early flowering and produced high quality of corms and cormels. On the contrary, the combined treatment of 6 days irrigation 
Scientific Journal of Agricultural Sciences 3 (1): 23-37, 2021

Table 4. Effects of the interaction between irrigation intervals, potassium fertilization, and humic acid on corms and cormels traits of Gladiolus grandiflorus cv. "Rose Supreme" plants during the 2018 and 2019 seasons.

\begin{tabular}{|c|c|c|c|c|c|c|c|c|c|c|c|c|c|c|}
\hline \multirow{2}{*}{$\begin{array}{l}\text { Irrigation } \\
\text { intervals }\end{array}$} & \multirow{2}{*}{ K fertilizer } & \multirow{2}{*}{$\begin{array}{c}\text { Humic } \\
\text { acid }\end{array}$} & \multicolumn{2}{|c|}{$\begin{array}{l}\text { Corm diameter } \\
(\mathrm{cm})\end{array}$} & \multicolumn{2}{|c|}{$\begin{array}{l}\text { Fresh weight } \\
\text { of corms (g) }\end{array}$} & \multicolumn{2}{|c|}{$\begin{array}{l}\text { Dry weight } \\
\text { of corms (g) }\end{array}$} & \multicolumn{2}{|c|}{$\begin{array}{c}\text { No. of } \\
\text { cormels/plant }\end{array}$} & \multicolumn{2}{|c|}{$\begin{array}{l}\text { Fresh weight of } \\
\text { cormels }(\mathrm{g})\end{array}$} & \multicolumn{2}{|c|}{$\begin{array}{l}\text { Dry weight of } \\
\text { cormels }(\mathrm{g})\end{array}$} \\
\hline & & & $1^{\mathrm{st}}$ & $2^{\text {nd }}$ & $1^{\mathrm{st}}$ & $2^{\text {nd }}$ & $1^{\mathrm{st}}$ & $2^{\text {nd }}$ & $1^{\mathrm{st}}$ & $2^{\text {nd }}$ & $1^{\mathrm{st}}$ & $2^{\text {nd }}$ & $1^{\mathrm{st}}$ & $2^{\text {nd }}$ \\
\hline \multirow{6}{*}{3 days } & \multirow{2}{*}{$\begin{array}{c}0 \% \\
\text { (Control) }\end{array}$} & $1 \mathrm{ml} / \mathrm{l}$ & $3.50 \mathrm{a}$ & $3.57 \mathrm{a}$ & $26.22 \mathrm{~h}$ & $24.39 \mathrm{~h}$ & $3.92 \mathrm{ef}$ & $3.66 \mathrm{~d}$ & $5.09 \mathrm{e}$ & $5.06 \mathrm{e}$ & $4.57 \mathrm{e}$ & $4.39 \mathrm{f}$ & $0.68 \mathrm{a}$ & $0.64 \mathrm{a}$ \\
\hline & & $2 \mathrm{ml} / 1$ & $3.69 \mathrm{a}$ & $3.79 \mathrm{a}$ & $28.96 \mathrm{~g}$ & $27.63 \mathrm{~g}$ & 4.74def & $4.41 \mathrm{bcd}$ & $6.54 \mathrm{e}$ & $6.42 \mathrm{de}$ & $4.85 \mathrm{ef}$ & 4.77def & $0.78 \mathrm{a}$ & $0.71 \mathrm{a}$ \\
\hline & \multirow{2}{*}{$50 \%$} & $1 \mathrm{ml} / 1$ & $4.01 \mathrm{a}$ & $4.20 \mathrm{a}$ & $38.08 \mathrm{ef}$ & $37.42 \mathrm{e}$ & $6.12 \mathrm{bcd}$ & $5.98 \mathrm{abc}$ & $8.52 \mathrm{~d}$ & $8.29 c$ & $5.66 c-f$ & $5.44 c-f$ & $0.91 \mathrm{a}$ & $0.81 \mathrm{a}$ \\
\hline & & $2 \mathrm{ml} / 1$ & $4.30 \mathrm{a}$ & $4.56 \mathrm{a}$ & $39.48 \mathrm{de}$ & $38.93 \mathrm{cde}$ & $6.71 \mathrm{abc}$ & $6.61 \mathrm{a}$ & $10.44 \mathrm{c}$ & $10.26 \mathrm{~b}$ & $6.90 \mathrm{a}-\mathrm{d}$ & $6.56 a-d$ & $1.12 \mathrm{a}$ & $1.05 \mathrm{a}$ \\
\hline & \multirow{2}{*}{$100 \%$} & $1 \mathrm{ml} / \mathrm{l}$ & $4.71 \mathrm{a}$ & $4.88 \mathrm{a}$ & $41.94 b c$ & $39.85 \mathrm{bc}$ & 7.40abc & $6.75 a$ & $14.42 \mathrm{ab}$ & $13.78 \mathrm{a}$ & 7.72ab & 7.39ab & $1.38 \mathrm{a}$ & $1.17 \mathrm{a}$ \\
\hline & & $2 \mathrm{ml} / 1$ & $4.79 a$ & $4.94 a$ & $44.25 \mathrm{a}$ & $42.71 \mathrm{a}$ & $8.20 \mathrm{a}$ & $7.54 \mathrm{a}$ & $15.83 \mathrm{a}$ & $15.01 \mathrm{a}$ & $8.49 a$ & $8.34 \mathrm{a}$ & $1.62 \mathrm{a}$ & $1.38 \mathrm{a}$ \\
\hline \multirow{6}{*}{6 days } & \multirow{2}{*}{$\begin{array}{c}0 \\
\text { (Control) }\end{array}$} & $1 \mathrm{ml} / \mathrm{l}$ & $3.42 \mathrm{a}$ & $3.49 \mathrm{a}$ & $25.12 \mathrm{~h}$ & $23.66 \mathrm{~h}$ & $3.81 \mathrm{f}$ & $3.57 \mathrm{~d}$ & $4.85 \mathrm{e}$ & $4.91 \mathrm{e}$ & $4.35 \mathrm{e}$ & $4.21 \mathrm{f}$ & $0.60 \mathrm{a}$ & $0.62 \mathrm{a}$ \\
\hline & & $2 \mathrm{ml} / 1$ & $3.66 \mathrm{a}$ & $3.70 \mathrm{a}$ & $28.06 \mathrm{~g}$ & $25.22 \mathrm{~h}$ & $4.55 \mathrm{def}$ & $4.32 \mathrm{~cd}$ & $6.30 \mathrm{e}$ & $6.18 \mathrm{e}$ & $4.70 \mathrm{ef}$ & $4.63 \mathrm{ef}$ & $0.73 \mathrm{a}$ & $0.65 \mathrm{a}$ \\
\hline & \multirow{2}{*}{$50 \%$} & $1 \mathrm{ml} / \mathrm{l}$ & $3.84 \mathrm{a}$ & $4.08 \mathrm{a}$ & $36.69 f$ & $35.64 f$ & $5.67 \mathrm{cde}$ & $5.74 \mathrm{abc}$ & $8.30 \mathrm{~d}$ & $8.08 \mathrm{~cd}$ & $5.37 \mathrm{def}$ & $5.26 \mathrm{def}$ & $0.84 \mathrm{a}$ & $0.76 \mathrm{a}$ \\
\hline & & $2 \mathrm{ml} / 1$ & $4.16 \mathrm{a}$ & $4.41 \mathrm{a}$ & $38.66 \mathrm{e}$ & $37.75 \mathrm{de}$ & $6.29 \mathrm{bcd}$ & $6.19 \mathrm{ab}$ & $9.77 \mathrm{~cd}$ & $10.06 \mathrm{~b}$ & $6.50 \mathrm{~b}-\mathrm{e}$ & $6.40 \mathrm{~b}-\mathrm{e}$ & $1.06 \mathrm{a}$ & $0.98 \mathrm{a}$ \\
\hline & \multirow{2}{*}{$100 \%$} & $1 \mathrm{ml} / \mathrm{l}$ & $4.58 \mathrm{a}$ & $4.71 \mathrm{a}$ & $40.49 \mathrm{~cd}$ & $39.46 \mathrm{~cd}$ & $6.92 \mathrm{abc}$ & $6.47 \mathrm{a}$ & $13.54 b$ & $13.23 \mathrm{a}$ & $7.29 \mathrm{abc}$ & $7.22 \mathrm{abc}$ & $1.33 \mathrm{a}$ & $1.11 \mathrm{a}$ \\
\hline & & $2 \mathrm{ml} / \mathrm{l}$ & $4.67 \mathrm{a}$ & $4.85 \mathrm{a}$ & $42.43 b$ & 41.31ab & 7.86ab & $7.21 \mathrm{a}$ & $14.61 \mathrm{ab}$ & $14.49 \mathrm{a}$ & $8.16 \mathrm{ab}$ & $8.10 \mathrm{ab}$ & $1.55 \mathrm{a}$ & $1.25 \mathrm{a}$ \\
\hline
\end{tabular}


intervals with $1 \mathrm{ml} \mathrm{l}^{-1} \mathrm{HA}$ without $\mathrm{K}$ led to late flowering.

In both seasons,. Three days irrigation intervals Glandules plants seemed to be more useful to irrigation than the six days irrigation intervals. For the $100 \%$ potassium sulphate fertilizer treated with Humic acid (2 mll-1), the 3 days irrigation was required for early flower production and produced high quality of corms and cormels. In contrast, 6 days irrigation led to late flowering produced by 1 mll-1 HA treatments (without K). Using 6 days of irrigation, it led to early flowering.

The significant improvement noticed in corms and cormels studied characteristics as a result of $\mathrm{K}$ treatment agree with those found by Barman et al. (1998), who reported that influence of K was much more pronounced on mass and size of corms and cormels. Moreover, Mukesh et al. (2001) illustrated that treatment of suitable amount of $\mathrm{K}$ caused in higher number and weight of corms/plant in Gladiolus plants.

Stimulating influences of $\mathrm{K}_{2} \mathrm{SO}_{4}$ on gladiolus corm and cormels yield as a product of $\mathrm{K}$ fertilization can be owing to the reason that $\mathrm{K}$ has a predominant action in plants and is involved in preservation of ionic balance in cell and ionic bounds to the enzyme pyruvate kinase which is essential in respiration and carbohydrate metabolism (Aisha et al., 2007). Misra (1994) mentioned that cormels improvement and formation is founded on leaves and when the leaves are good sufficient, with proper high plant and leaves number, the plant produce enough photosynthates. Also, plant height has a helpful direct influence on bulb diameter, mass and yield (Haydar et al., 2007). Moreover, the stimulating influence of dry mass caused through enhancement of cell division and chlorophyll accumulation (Amin et al., 2007). Furthermore, Ramzan et al. (2010) found that the positive result of $\mathrm{KNO}_{3}$ might be owing to the obtainability of $\mathrm{N}$ and $\mathrm{K}$ that caused in more plant height which contributing towards corm mass and diameter. Ghasemi et al. (2016) mentioned that treating plants with $5 \mathrm{~kg} \mathrm{ha}^{-1} \mathrm{HA}$ augmented main bulbs mass and total bulbs mass on tuberose plants. In this regards, significant differences were detected on vegetative growth, flowering traits, corms and cormels characteristics as a result the influence of $200 \mathrm{~kg} \mathrm{fed}^{-1}$ $\mathrm{N}$ with $350 \mathrm{mg} \mathrm{l}^{-1} \mathrm{HA}$ on Gladiolus plants (El-Kot et al., 2020).

The interaction between irrigation intervals and soil dressing applications of potassium and humic acid treatments showed that the combination of irrigation interval at 3 days, $100 \% \mathrm{~K}$ and $2 \mathrm{ml} \mathrm{l}^{-1} \mathrm{HA}$ produced the highest values of vegetative growth, flowering yield, quality of corms and cormels compared with the other applications. Investigators speculate that the phytohormone properties of humic acid can play a causal important in water deficit stress amelioration (Chen et al., 2004; Delfine et al., 2005).

\subsection{Chlorophylls (a and b) content in fresh leaves (mg/g FW):}

As presented in Fig (1) the data showed that leaf chlorophylls ( $a$ and $b$ ) content seemed to be significantly affected by applying irrigation intervals and fertilizer treatments compared to the control.

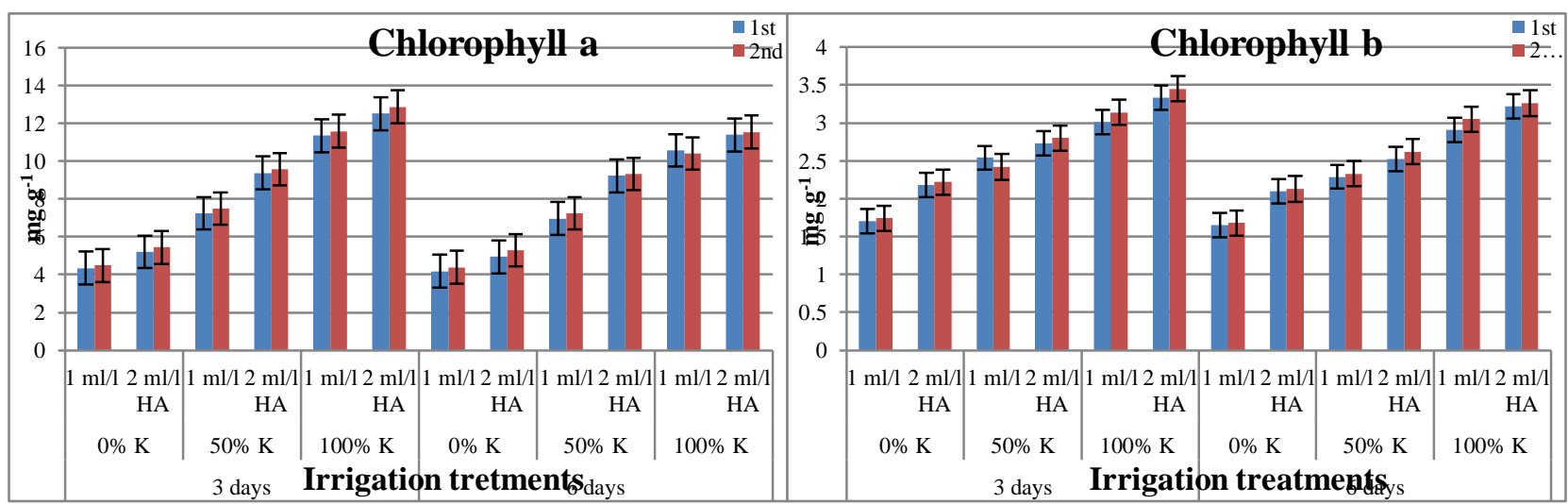

Fig 1. Effect of irrigation intervals ( 3 and 6 days), potassium sulphate $(0,50$ and $100 \% \mathrm{~K})$ and humic acid ( 1 and $2 \mathrm{ml}$ l-1 HA) on leaf chlorophyll contents of Gladiolus grandiflorus L. during 2018 and 2019 seasons. 


\section{Scientific Journal of Agricultural Sciences 3 (1): 23-37, 2021}

The highest values of chl. (a) were obtained as a result of low of 3 days irrigation intervals and high levels fertilizing the plants through $100 \% \mathrm{~K}$ with $2 \mathrm{ml}$ $1^{-1}$ as soil dressing (Fig. 1). Also, it can be observed that, applying $100 \% \mathrm{~K}$ with $1 \mathrm{ml} \mathrm{l}^{-1} \mathrm{HA}$ as soil dressing produced higher chlorophyll (a) values.

Concerning the effects of irrigation intervals and levels of $\mathrm{K}$ and HA on chl. (b), the data in Figure (1) showed that the highest values of chl. (b) were noted as a result of 3 days irrigation intervals and fertilizing the plants using $100 \% \mathrm{~K}$ by $2 \mathrm{ml} \mathrm{l}^{-1}$ as soil dressing. Furthermore, applying 6 days irrigation intervals and $100 \% \mathrm{~K}$ with $2 \mathrm{ml} \mathrm{l}^{-1}$ as soil dressing gave superior values than those obtained with fertilizing the plants with control treatment.

These results are in agreement with those found by Chouhan et al. (2014), who stated that the high chlorophyll contents in Gladiolus fresh leaves were noted as a result of fertilizing the plants with $\mathrm{K}$ level of $1.8 \mathrm{~g} \mathrm{plant}^{-1}$. Similar trend of effects were stated by Mohsen et al. (2016), who detected that the total chlorophyll contents of gladiolus plants were augmented reliably when $\mathrm{K}$ was applied in enough quantity.

Chlorophyll $\mathrm{a}$ and $\mathrm{b}$ contents in leaves were diminished by extending the intervals between irrigations. Deficit irrigation stress cans diminution stomatal conductance (Fort et al., 1997) and level of chl. a and b (Pukacki and Rozek, 2005), leading to a reduction (3-7 folds) in photosynthetic activity in Acacia (Liu et al., 2004). The plants which were watered at short intervals (3 days) contained higher levels of chl. a and b in leaves than those irrigated at comparatively long intervals. The highest values of chl. a and b in Gladiolus leaves were obtained when plants sprayed with $2 \mathrm{ml} \mathrm{l}^{-1} \mathrm{HA}$ and $100 \% \mathrm{~K}$. This effect is in agreement with that demonstrated by Zaghloul et al. (2009) on Thuja and Farahat et al. (2012) on Khaya senegalensis, who reported that treatment of plants with $\mathrm{K}$ increased $\mathrm{Chl}$. $\mathrm{a}$ and $\mathrm{b}$ in fresh leaves.

The significant increase in photosynthetic pigment contents as a result of applying $\mathrm{K}$ with $\mathrm{HA}$ treatments can be owing to accumulate the obtainability of $\mathrm{N}$, which might led to increase chl. formation owing to the importance of $\mathrm{N}$ in chl. conformation and synthesis, therefore cumulative its absorption by the plant, quickening of $\mathrm{N}$ uptake, enhancing $\mathrm{N}$ metabolism, stimulation of assimilation and production of protein that finally increase chl. contents (Haghighi et al., 2012). Humic acid has a positive influence on plant physiology (Turkmen, et al., 2004; Atefe and Ali, 2012), so that, level of $2 \mathrm{ml} \mathrm{l}^{-}$

${ }^{1} \mathrm{HA}$ was effective on cumulative of chl. content.

\subsection{Chemical components ( $N, P, K$, and Carbohydrate\% ) of leaves:}

The obtained data in Figure (2) showed that irrigation intervals and fertilizing the plants treatments significantly affected leaf nutrient contents $(\mathrm{N}, \mathrm{P}, \mathrm{K}$, and carbohydrates percentage) compared to the control.

A consequence of the plant leaves analyses for their N, P, K, and carbohydrate percentage are showed in Figure (2A, B, C, and D). The results illustrated that the highest $\mathrm{N}, \mathrm{P}, \mathrm{K}$, and carbohydrates percentages were achieved as a result of applying 3 days irrigation intervals and high levels of fertilizers $(100 \% \mathrm{~K}$ with 2 $\left.\mathrm{ml} \mathrm{l}^{-1} \mathrm{HA}\right)$ as soil dressing.

Furthermore, it was noticed that 6 days irrigation intervals and high levels of fertilizers $(100 \%$ $\mathrm{K}$ with $2 \mathrm{ml} \mathrm{l}^{-1} \mathrm{HA}$ ) as soil dressing gave high $\mathrm{N}, \mathrm{P}$, $\mathrm{K}$, and carbohydrates percentages than those other treatments applied.

Our results are in agreement with those reported by Lin and Danfeng (2003), who detected an increase in growth traits, photosynthetic rate; chlorophyll content and NPK contents related with enhancement of $\mathrm{K}$ doses. Also, Zhang et al. (2002) suggested that $\mathrm{K}$ application affected growth, photosynthesis and elements uptake of melon. ElTohamy et al. (2011) mentioned that K, N and P levels in carrot foliage were significantly increased by $\mathrm{K}$ treatment as compared with the control. Sarrwy et al. (2010) found that spraying Picual olive trees with $\mathrm{KNO}_{3}$ had a positive effect on leaf element contents under sandy soil. Moreover, Mostafa and Saleh (2006) illustrated that treating Balady mandarin with $\mathrm{K}$ from numerous forms i.e. $\mathrm{KNO}_{3}$ or $\mathrm{KH}_{2} \mathrm{PO}_{4}$ had a helpful influence on leaf mineral of mandarin since they elevated $\mathrm{K}, \mathrm{N}$ and $\mathrm{P}$ concentrations in the leaves. They mentioned that application of K, improved the NK and chl. content. Sarrwy et al. (2012) studied the effect of $\mathrm{K}$ foliar application in different forms i.e., $\mathrm{KTS}, \mathrm{KNO}_{3}$ and MKP and different levels on mandarin trees either post or pre bloom. The data illustrated that all $\mathrm{K}$ forms induced observed raise in leaf elements status. Pande et al. (2012) demonstrated that increased accumulation of $\mathrm{N}, \mathrm{P}, \mathrm{K}$, and micronutrients ( $\mathrm{Mn}, \mathrm{Cu}, \mathrm{Fe}$, and $\mathrm{Zn}$ ) in soybean leaves was obtained when plants sprayed with $\mathrm{K}$ fertilizer Mohsen (2013) found that spraying $\mathrm{KNO}_{3}$ on cucumber either mixture with HA significantly affected leaves chl. and NK contents. Manju et al. 


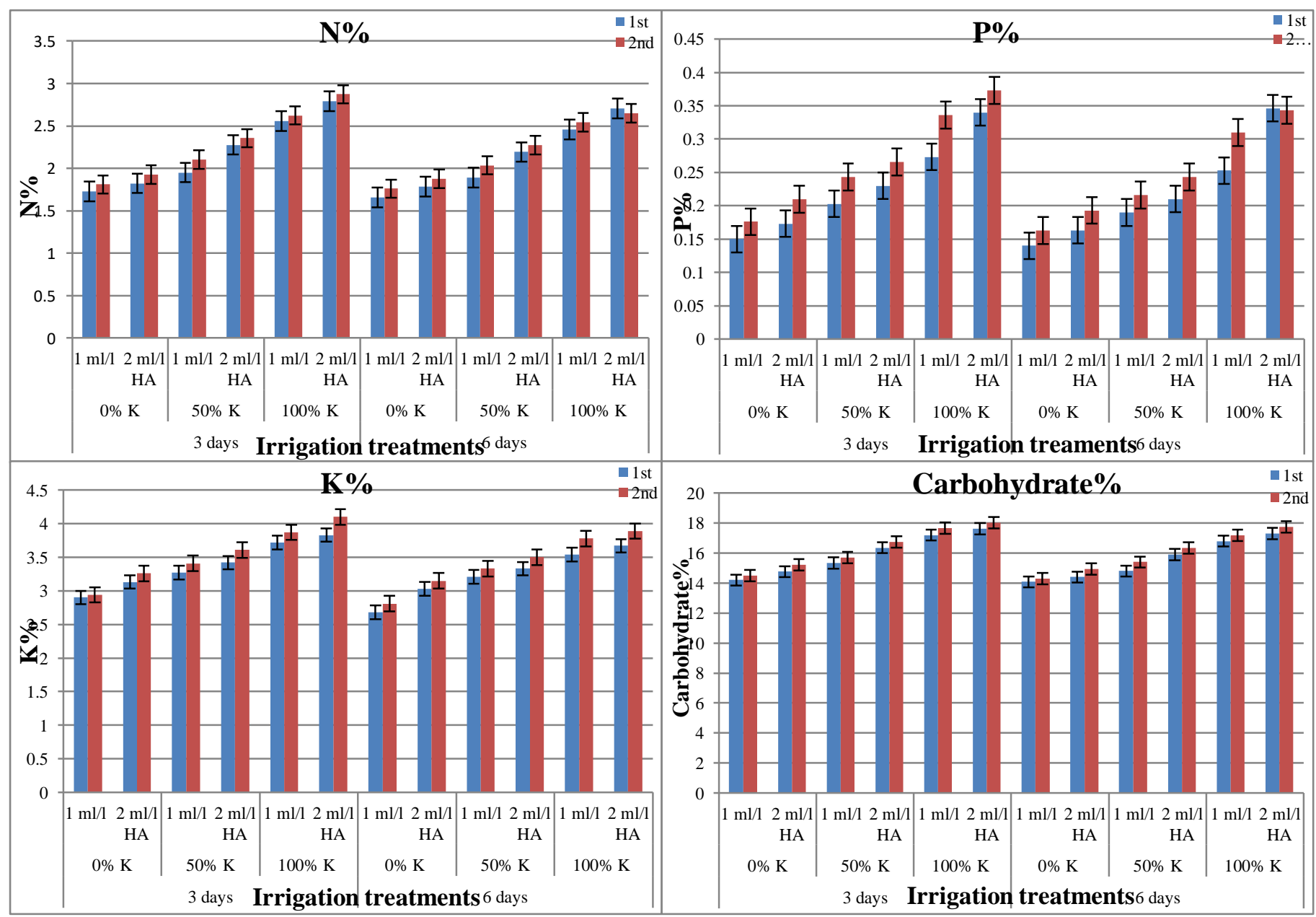

Fig. 2. Effect of irrigation intervals ( 3 and 6 days), potassium sulphate $(0,50$ and $100 \% \mathrm{~K})$ and humic acid ( 1 and $2 \mathrm{ml} / \mathrm{l}$ HA) on chemical components (N, P, K, and carbohydrate\%) in leaves of Gladiolus grandiflorus L. during 2018 and 2019 seasons.

(2014) evaluated the efficiency of soil and application of $\mathrm{K}$ on leaf mineral levels of soybean plants.

Data showed that significant differences were detected on $\mathrm{N}, \mathrm{P}$ and $\mathrm{K}$ contents in leaves as a result of the influence of $\mathrm{N}$ with $\mathrm{HA}$ on chemical constituents of Gladiolus (El-Kot et al., 2020). Abd-All and ElNamas (2017) stated a positive increase in N, K and P of potato plant getting $4 \mathrm{~kg} \mathrm{fed}^{-1} \mathrm{HA}$ alone or in combination with $\mathrm{K}$ as a spray application. Also, ElBably (2017) reported that treatment of tuberose plants with $9 \mathrm{ml} \mathrm{l}^{-1} \mathrm{HA}$ as soil drench resulted in a significant increase in $\mathrm{N}, \mathrm{K}$ and $\mathrm{P}$ in leaves compared to control plants. Furthermore, Fahmy and Hassan (2019) reported that the mixture among $100 \%$ of suggested level with $41 \mathrm{fed}^{-1} \mathrm{HA}$ gave a positive influence on chemical constituents $(\mathrm{K}, \mathrm{N}$ and $\mathrm{P})$ of Hibiscus subdariffa L. compared to untreated plants.

\section{CONCLUSION}

From our results, it can be illustrated that when applying irrigation interval (3 days), 100\% K and $2 \mathrm{ml} \mathrm{l}^{-1} \mathrm{HA}$ as a soil dressing, it has a potential influence on growth traits. Furthermore, $\mathrm{K}$ and HA can be used a recommended sandy soil HA and $\mathrm{K}$ for cumulative elements uptake and thus stimulating growth and flowering traits of gladiolus plants cv. "Rose Supreme".

\section{REFERENCES}

AOAC (1995). Association of Official Agricultural Chemists. Official Methods of Analysis. 10th Ed. AOAC, Wash., DC.

Abbasi NA, Hafiz IA, Ahmad T, Saleem N (2005). Growing Gladiolus. Proceedings of the National Seminar on Streamlining. Production and export of cut flowers and house plants. Hort. 
Foundation. Pak., 2nd -4th March. Islamabad Abd-All A, El-Namas AE (2017). Effect of humic acid and foliar application of different potassium sources on yield, quality and water use efficiency of sweet potato grown under drip irrigation in sandy soil. Alex. sci. Exchange J., 38 (3): 543-553.

Abdel Mawgoud A, El-Greadly MRN, Helmy YI, Singer SM (2007). Responses of tomato plants to different rates of humic based fertilizer and NPK fertilization. J. Appl. Sci. Res., 3: 169-174.

Abe H, Nakai T (1999). Effect of water status within a tree on tracheid morphogenesis in Cryptomeria japonica D. Don Trees: Structure and Function, 14(3): $124-129$.

Aisha AH, Rizk FA, Shaheen AM, Abdel- Mouty MM (2007). Onion plant growth, bulb yield and its physical and chemical properties as affected by organic and natural fertilization. Res. J. Agric. Biol. Sci.,3(5): 380-388.

Ali, A.A.G. and S.A.E. Mowafy. (2003). Effect of different levels of potassium and phosphorus fertilizer with the foliar application of Zinc and boron on peanut in sandy soil. Zagazig J. Agric. Res., 30: 335-358.

Amin AA, Rashad EM, EL-Abagy HMH (2007). Physiological effect of indole-3-butyric acid and salicylic acid on growth, yield and chemical constituents of Onion. Plt. J. Appl. Sci. Res., 3(11): 1554-1563.

Arvinder S, Sharma B, Dilta B, Nomita L, Gupta y, Bhardwaj S (2015). Effects of fertilization on quality flower production and foliar nutrient content of carnation (Dianthus caryophyllus , L.) cv. Master. Bangladesh J. Bot. 44(1): 133-137.

Atefe A, Ali T (2012). Effect of Humic Acid on Nutrient Uptake and Physiological Characteristic Fragaria ananassa var: Camarosa. J. Biol. Environ. Sci., 6: 77-79.

Ayoub II (2005). Effect of fertigation and plant population on growth, yield and storability of sweet potato grown under sandy soil conditions. Ph.D. Thesis, Fac. Agric., Zagazig Univ., Egypt.

Azizi M (1998). The effect of different irrigation regimes and potassium fertilizer on agronomic, physiological, and biochemical properties of soybean.PhD Thesis in Agriculture, Mashad University, $143 \mathrm{p}$.

Babar A, Jawad A, Sayyed WAB, Muhammad I, Waqas $K$ (2017). Effect nitrogen and humic acid levels on plant height and number of florets per spike of Gladiolus cultivars. Int. J. Environ. Sci. Nat. Res.; 7(1): 555701.

Baldoto MA, Baldoto LEB (2013). Gladiolus development in response to bulb treatment with
Pakistan, pp. 145-147.

different concentrations of humic acids. Rev. Ceres, Vicosa. 60 (1): 138-142.

Barman G, Chanda S, Roychoudhary N (1998). Production of corms and cormels of Gladiolus through application of N, P and K. Horticulture Journal, 11: 87-92.

Bates LS, Waldren RP, Teare ID (1973). Rapid determination of free proline for water stress studies. Plant Soil, 39: 205-207.

Bazaraa WM, Abdal-Fattah Gehan H, Nabih A (2012). Response of Gladiolus cv. Novalux to some irrigation intervals, different levels of some biostimulants and their interaction on plant development, corms and cormlets production and chemical constituents of the new corms Egypt. J. Hort. Sci., 39(2): $121-147$.

Butt SJ ( 2005). Effect of N, P, K on some flower quality and corm yield haracteristics of gladiolus. Tekirdag Journal of Agriculture, 2 (3): 212-214.

Cacco G, Attina E, Gelsomino A, Sidari M (2000). Effect of nitrate and humic substances of different molecular size on kinetic parameters of nitrate uptake in wheat seedlings. J. Plant Nutr. Soil Sci., 163: 313320.

Chen Y, De Nobili M, Aviad T (2004). Stimulatory effects of humic substances on plant growth. In: F. Magdoff and R.W. Ray, (eds.) Soil Organic Matter in Sustainable Agriculture, pp: 103-129.

Chouhan P,Vidhya SM, Vijay R (2014). Effect of NPK on Physico- chemical Parameters of Gladiolus (Gladiolus hybrida) cv. White Prosperity. International Journal of Scientific and Research Publications, 4(12):1-5.

Delfine S, Tognetti R, Desiderio E, Alvino A (2005). Effect of foliar application of $\mathrm{N}$ and humic acids on growth and yield of durum wheat. Agron. Sustain. Dev., 25: 183-191.

El-Bably SMZ (2017). Effect of some natural material additives on growth and flowering of tuberose (Polianthes tuberosa, L.) bulbs. J. Plant Prod., 8 (9): 895-906.

El-Hanafy SH, Nabih A, Badawy OEF (2006). Effect of different irrigation periods and chemical fertilization on growth, flowering, bulb production and chemical constituents of Ornithogalum thyrsoides, Jacq. Bull. Fac. Agric. Cairo Univ., 57: 745 -774.

El-Khateeb MA, El-Leithy AS, Aljemaa BA (2011). Effect of mycorrhizal fungi inoculation and humic acid on vegetative growth and chemical composition of Acacia saligna Labill. Seedlings under different irrigation Intervals. J. Horticultural Science and Ornamental Plants, 3: 283-289. 
El-Kot HRM, Abdallah SA, Hassan HMS, Ali MAM (2020). Effect of chemical nitrogen fertilizer level and humic acid rate on Gladiolus grandiflorus. SINAI Journal of Applied Sciences, 9(1): 029-040.

El-Shakhs MH, Auda MS, Ahmed AK (2002). Effect of potassium sulphate and soil moisture on water use, growth and flowering of Dahlia pinnata Cav. J. Agric. Res. Tanta Univ., 28(1): $132-156$.

El-Tohamy WA, El-Abagy HM, Badr MA, AbouHussein SD, Helmy YI (2011). The influence of foliar application of potassium on yield and quality of carrot (Daucus carota, L.) plants grown under sandy soil conditions. Aust. J. Basic \& Appl. Sci., 5(3): 171174.

Fahmy AA, Hassan HMS (2019). Influence of different NPK fertilization levels and humic acid rates on growth, yield and chemical constituents of roselle (Hibiscus subdariffa L.). Middle East. J. Agric. Res., 8(4): 1182-1189.

Farahat MM, Mazhar AAM, Mahgoub MH (2012). Response of Khaya senegalensis seedlings to irrigation intervals and foliar application of humic acid. Journal of Horticultural Science \& Ornamental Plants, 4(3): 292-298.

Fort C, Fauveau ML, Muller F, Pabel P, Granier A, Dreyer E (1997). Stomatal conductance, growth and root signaling in young oak seedling subjected to partial soil drying, Tree Physiol., 17: 281-289.

Ghasemi H, Rezaei M, Asghari H, GhorbaniGhouzhdi H, Sharififar A (2016). cultivation of tuberose in pot and field with humic acid treatments under a semi-arid climate. Indian J. Hort., 73(3): 391395.

Ghorbani S, Khazaei HR, Kafi M, BanayanAval M (2010). The effect of adding humic acid to irrigation water on yield and yield components of corn. Journal of Agriculture ecology, 2: 123-131.

Haghighi M, Heidarian S, Da Silva TJA (2012). The effect of titanium amendment in $\mathrm{N}$-withholding nutrient solution on physiological and photosynthesis attributes and micronutrient uptake of tomato. Biol Trace Elem Res DOI 10.1007/s12011-012-9481-y.

Haghighi S, Sakinejad T, Lack SH (2011). Evalution of changes the equalization and quantitative yield of horse been (Vicia faba) plant in the level of humic acid fertilizer. Life Sci., 8(3): 133-144.

Haydar A, Sharker N, Ahmed MB, Hannan MM, Razvi MA, Hossain M, Hoque A, Karim R (2007). Genetic variability and interrelationship in Onion (Allium cepa ,L.). Middle East. J. Sci. Res.,2(4): 132134.

Lin Duo, Danfeng $\mathrm{H}$ (2003). Effects of potassium levels on photosynthesis and fruit quality of muskmelon in culture medium. Acta Horticulturae Sinica., 30(2): 221-223.

Liu Li-Xia, Shou-Min Xu, Woo KC (2004). Watering regime effects on photosynthesis and the xanthophyll cycle in the tropical tree species Acacia auriculiformis in North Australia, N. Zealand J. Bot., 42: 949-957.

Manning J, Goldblatt $P$ (2008). The iris family: Nature history and classification. Port land, Oregon. Timber press. 138-142.

Mazher AAM, Yassen AA, Zaghloul SM (2007). Influence of foliar application of potassium on growth and chemical composition of Bauhinia variegata seedlings under different irrigation intervals. World Journal of Agricultural Sciences, 3(1): 23-31.

Michail T, Walter T, Astrid W, Walter G, Dieter G, Maria SJ, Domingo M (2004). A survey of foliar mineral nutrient concentrations of Pinus canariensis at field plots in Tenerife. Forest Ecology and Management, 189: 49-55.

Misra RL, (1994). Effect of leaf and spike clippings on corm and cormel yield of gladiolus. in: Prakash J, Bhandary kR ed. floriculture-technology, trades and trends. india, Oxford \& IBh Publishing Company. Pp. 55-58.

Mohsen B (2013). Effect of foliar application of humic acid and potassium nitrate on cucumber growth. Bull. Env. Pharmacol. Life Sci., 2(11): 03-06.

Mohsen B, Imran K, Rashid W, Khan Q, Mohsin T, Muhammad Z, Iftikhar A (2016). Growth and corm production of Gladiolus grandiflorus $\mathrm{L}$. 'Essential' under different NPK regimes. Journal of Ornamental Plants, 6(1): 11-19.

Mohsin B, Imran K, Rashid W, Khan Q, Mohsin, T, Muhammad Z, Iftikhar A (2015). Growth and corm production of Gladiolus grandiflorus, L. 'Essential' under different NPK regimes. Journal of Ornamental Plants, 6(1): 11-19.

Mukesh K, Chattappadhyay TK, Das DK, Kumar M (2001). Effect of Foliar Application of Zinc, Copper and Iron on the Yield and Quality of Gladiolus cv. Mirela. J. Interacademicia, 5: 300-303.

Mostafa EAM, Saleh MMS (2006). Response of Balady Mandarin trees to girdling and potassium sprays under sandy soil conditions. Res. J. Agric. and Biol. Sci., 2(3): 137-141.

Motaghi S, Nejad TS (2014). The effect of different levels of humic acid and potassium fertilizer on physiological indices of growth.

Nabih A, Aly AA, Nada MK (1992a). Growth, flowering and corm productivity of Freesia refracta cv. Aurora as affected by different irrigation periods and 
chemical fertilization Egypt, J. Appl. Sci., 7(6): 265 283.

Nabih A, Nada MK, El-Tantawy A (1992b). Effect of some irrigation periods and chemical fertilization on growth, flowering and bulbs productivity of Polianthes tuberosa plant. Egypt, J. Appl. Sci., 7(8): 190-220.

Nonami H (1980). Plant water relations and control of cell elongation at low water potentials. J. Plant Res., 111: 373-382.

Pande M, Goli MB, Epps T, Bellaloui N (2012). Seed protein, oil, fatty acids, and mineral concentration as affected by foliar K-Glyphosate applications in soybean cultivars. Agricultural Sciences, 3: 848-853.

Pandey RK, Rathore P, Singh MK, Rathore P (2000). Effect of different levels of $\mathrm{N}$ and $\mathrm{P}$ on growth of Gladiolus under Agra conditions. J. Orn. Hort., 3: 60-1.

Passioura JB (2007). The drought environment: physical, biological and agricultural perspectives. J. Exp. Bot., 58: 113-117.

Patra SK, Mohanty CR (2015). Vase life study in different varieties of gladiolus. I. J. Agri. 5(2): 27-32.

Porra RJ, Thompson WA, Kriedemann PE (1989). Determination of accurate extinction coefficients and simultaneous equations for assaying chlorophylls a and $b$ extracted with four different solvents: verification of the concentration of chlorophyll standards by atomic absorption spectroscopy. Biochem. Biophys. Acta 975, 384-394.

Pukacki PM, Rozek EK (2005). Effect of drought stress on chlorophyll a fluorescence and electrical admittance of shoots in Norway spruce seedlings. Trees-structure. Funct., 19: 539-544.

Ramzan A, Hafiz A, Ahmad T, Abbasi NA (2010). Effect of priming with potassium nitrate and dehusking on seed germination of Gladiolus alatus. Pak. J. Bot., 42(1): 247-258.

Sabzevari SH, Khazaei R (2009). The effect of foliar spray of different levels of humic acid on growth characteristics and yield of wheat, Pishtaz cultivar. Journal of Agricultural Ecology, 1:53-63.

Sarrwy SMA, Enas A, Hassan HSA (2010). Effect of foliar spray with potassium nitrate and monopotassium phosphate on leaf mineral contents, fruit set, yield and fruit quality of Picual olive trees grown under sandy soil conditions. American-Eurasian J. Agric and Environ. Sci., 8(4): 420-430.

Sarrwy SMA, El-Sheikh M, Kabeil SS, Shamseldin A (2012). Effect of foliar application of different Potassium forms supported by Zinc on leaf mineral contents, yield and fruit quality of "Balady" mandarin trees. Middle -East Journal of Scientific Research, 12 (4), 490- 498.

Sharifi M, khattak RA, Sarir MS (2002). Effect of different levels of lignitic coal dervedhumic acid on growth of surface-irrigated wheat. Agricultural science, 52: 207-210.

Thalooth AT, Tawfic MM, Magda Mohamed H (2006). Comparative study on the effect of foliar application of Zinc, potassium and magnesium on growth, yield, and some chemical constituents of mungbean plants grown under water stress conditions. World J. Agric. Sci., 2: 37-46.

Trevisan S, Francioso O, Quaggiotti S, Nardi S (2010). Humic substances biological activity at the plant-soil interface from environmental aspects to molecular factors. Plant Signal Behav., 5: 635-643.

Turkmen O, Dursun A, Turan M, Erdinc C (2004). 'Calcium and humic acid affect seed germination, growth and nutrient content of tomato (Lycopersicon esculentum L.) seedlings under saline soil conditions. Acta Hort. Scandinavica, Section B- Plant Soil Sci., 54: 168-174.

Xiumei L, Yaping $L$ (2003). An experiment on the best application amount of $\mathrm{K} 2 \mathrm{SO} 4$ for potato (Solanum tuberosum) grown in chernozem soil. Chinese Potato Journal , 17:23-24.

Younis A, Pervez MA, Riaz A (2006). Effect of different levels of nitrogen, phosphorous and potash fertilizers on growth of Dahlia. Caderno de Pesquisa, Serie Biologia, 18: 8-13.

Zaghloul SM, El-Quesni FEM, Mazhar AAM, (2009). Influence of potassium humate on growth and chemical constituents of Thuja orintalis L. seedlings. Ozean Journal of Applied Science, 2: 73-78.

Zhang A, Huang Dan F, Hou Z (2002). Effect of potassium nutrient on development and photosynthesis of melon plant. Journal of Shanghai Agricultural College, 20(1): 13-17.

Zubair M (2011). Effect of potassium fertility levels on gladiolus yield quality of cut flowers and corm production. Egyptian Academic Journal of Biological Sciences, 2: 17-27. 
Amani Ismail Adam., 2021

الملخص العربي

دراسات علي استجابة نبات الجلاديولس لحمض الهيوميك والبوتاسيوم وطول الفترة بين الريات

أماني اسماعيل حسن ادم

فرع بحوث نباتات الزينة بأنطونياد الإسكندرية- قسم بحوث الزينة وتتسيق الحدائق معهد بحوث البساتين مركز البحوث الزراعية

أجريت هذه الدراسة خلال موسي 2018 - 2019، في فرع بحوث أنطونياد ، معهد بحوث البساتين، وزارة الزراعة، الاسكندرية،

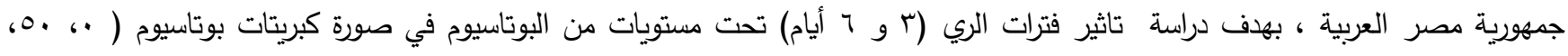

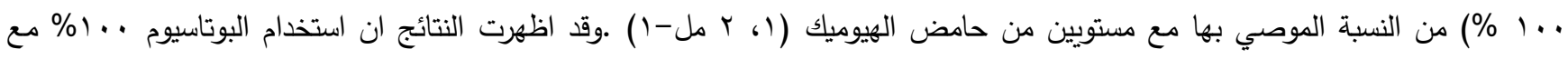

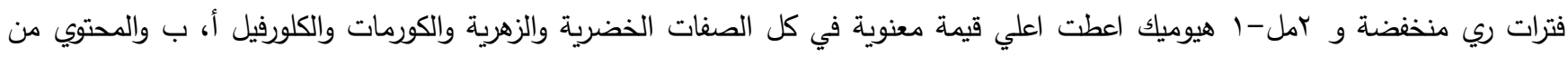
النيتروجين والفوسفور والبوتسيوم للنبات كما تبين انها قد اعطت قيمة غير معنوية لصفات عرض الورقة وقطر الكورمات والوزن الجاف للكورمات ،

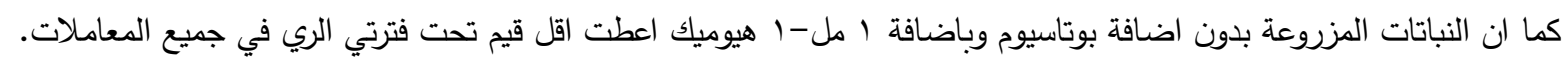

